\title{
Evaluation of Compost and Soil Mix Ratios for Perennial Ryegrass Establishment on Topsoil and Subsoil
}

\author{
Benjamin Pease ${ }^{1}$, Grant L. Thompson ${ }^{1}$, and Adam W. Thoms ${ }^{1}$
}

AdDitionAl INDEX wORDs. electrical conductivity, Lolium perenne, nitrate content, turfgrass

Summary. Soil degradation during construction often results in soil loss through erosion and reduced vegetation establishment. Composted organic materials are used to restore soil health of compromised urban soils when planting trees and shrubs; however, less is known about compost amendments for turfgrass establishment. The objective of this trial was to determine the effects of differing compost incorporation rates in two soil types on perennial ryegrass [PR (Lolium perenne)] establishment. The hypothesis was that as compost incorporation rates increase, turfgrass germination would increase until the compost rate becomes detrimental to turfgrass germination because of increased nitrate content and electrical conductivity (EC) levels. A salt-sensitive PR cultivar and a salt-tolerant PR cultivar were seeded into a loam topsoil and a clay subsoil at soil:compost volume ratios of 100:0, 80:20, 70:30, 60:40, 50:50, 40:60, and 0:100 using a mixed-source mature compost. Percent green cover (PGC) and leachate $\mathrm{pH}, \mathrm{EC}$, and nitrate content were measured during the 5-week establishment period. This trial showed that with a suitable topsoil, compost incorporation may be unnecessary to obtain acceptable PGC, but that compost additions (30\% to $40 \%)$ to a clay subsoil achieve faster establishment while limiting the potential for reduced establishment because of increased nitrate content or EC associated with greater levels of compost incorporation. The $\mathrm{EC}$ or $\mathrm{pH}$ of soil:compost leachate was not found to predict turfgrass establishment. This trial suggests that soil type should be considered when making compost use rate recommendations; however, further research is needed to link compost physiochemical properties to compost use rates.

S oil degradation during construction is a worldwide problem that contributes to the challenges of re-establishing vegetation after construction activities. Failure to establish vegetation can result in soil loss

Received for publication 1 Sept. 2021. Accepted for publication 13 Jan. 2022.

Published online 11 February 2022

${ }^{1}$ Department of Horticulture, Iowa State University, 2206 Osborn Drive, Ames, IA 50011

Current address for B.P.: The Andersons Inc., P.O Box 119, 1947 Briarfield Blvd., Maumee, OH 43537

We thank Colin Laswell, Ethan DenBeste, and Nate Underwood for help with data collection. We thank Alexandria Logan, Megan Blauwet, and Patrick Galland for assistance with laboratory techniques. We thank Michael Castellano, Iowa State University (ISU) Department of Agronomy, for the use of lab oratory space and equipment, Peter Lawlor, ISU Department of Horticulture, for greenhouse management assistance, and Steve Jonas, ISU Compost Facility, for compost preparation and availability. We also thank Jacklin Seed and Iowa Sports Turf for the donation of supplies.

A.W.T. is the corresponding author. E-mail: athoms@iastate.edu.

This is an open access article distributed under the CC BY-NC-ND license (https://creativecommons. org/licenses/by-nc-nd/4.0/).

https://doi.org/10.21273/HORTTECH04939-21 through erosion and reduced water quality through sedimentation and associated nutrients (Iowa Department of Natural Resources, 2006). Therefore, the successful growth of vegetation to protect soil is vital for the provision of ecosystem services and environmental protection. There has been increasing interest in using composted organic materials from numerous sources as a means of ameliorating compromised soils to restore soil health and improve vegetation establishment. Although much research has focused on soil restoration with compost for planting trees (Layman et al., 2016; McGrath and
Henry, 2016), less research has been conducted regarding the use of composts and turfgrass establishment despite the widespread use of turfgrass as a groundcover for postconstruction soil stabilization (Turgeon and Kaminski, 2019). Because compost is a variable product that depends on many factors, including source stock, age, and processing techniques (Heyman et al., 2019), recommendations for using compost that focus on physiochemical compost properties rather than simply volumetric proportions may prove more useful for landscape managers seeking to influence soil properties such as bulk density and nutrient and/or waterholding capacity.

Compost properties and use guidelines have been reported and identified for remediation of urban soils (Heyman et al., 2019; Sax et al., 2017), for urban tree plantings (Layman et al., 2016), and for roadside tree plantings (McGrath and Henry, 2016). However, because of the common practice of establishing turfgrass by seeding, as opposed to mature plantings of trees and shrubs, compost use recommendations in a turfgrass situation may require more information such as salt or nutrient levels of a compost. Compost amendment guidelines for establishing turfgrass have been mostly based on volumetric amounts from research in agricultural and orchard settings (Cogger, 2005); therefore, more specific compost measurements such as soluble salt levels are needed to refine compost use recommendations for many common turfgrass species. The soluble salt level measurement was chosen because it can be read by many handheld devices, elevated levels can impact turfgrass establishment, and it is widely used in greenhouse crop management.

Turfgrass is often established from seed; therefore, available soil moisture during germination is critical

\begin{tabular}{llll}
\hline $\begin{array}{l}\text { Units } \\
\text { To convert U.S. to SI, } \\
\text { multiply by }\end{array}$ & U.S. unit & SI unit & $\begin{array}{l}\text { To convert SI to U.S., } \\
\text { multiply by }\end{array}$ \\
\hline 29.5735 & $\mathrm{fl} \mathrm{oz}$ & $\mathrm{mL}$ & 0.0338 \\
2.54 & inch $(\mathrm{es})$ & $\mathrm{cm}$ & 0.3937 \\
48.8243 & $\mathrm{lb} / 1000 \mathrm{ft}^{2}$ & $\mathrm{~kg} \cdot \mathrm{ha}^{-1}$ & 0.0205 \\
1 & millimicron $(\mathrm{s})$ & $\mathrm{nm}$ & 1 \\
1 & mmho/cm & $\mathrm{dS} \cdot \mathrm{m}^{-1}$ & 1 \\
1.7300 & $\mathrm{Oz} / \mathrm{inch}^{3}$ & $\mathrm{~g} \cdot \mathrm{cm}^{-3}$ & 0.5780 \\
1 & $\mathrm{ppm}$ & $\mathrm{mg} \cdot \mathrm{kg}^{-1}$ & 1 \\
1 & $\mathrm{ppm}$ & $\mathrm{mg} \cdot \mathrm{L}^{-1}$ & 1 \\
$\left({ }^{\circ} \mathrm{F}-32\right) \div 1.8$ & ${ }^{\circ} \mathrm{F}$ & ${ }^{\circ} \mathrm{C}$ & $\left({ }^{\circ} \mathrm{C} \times 1.8\right)+32$
\end{tabular}

Horflechnology · April 2022 32(2) 
for turfgrass establishment. In addition to inadequate water, a high soluble salt content in soils can quickly dehydrate a germinating seedling. Soluble salt levels more than $4 \mathrm{dS} \cdot \mathrm{m}^{-1}$, as measured by EC, can reduce the growth and yield of even salt-tolerant crops such as bermudagrass (Cynodon dactylon), sugar beet (Beta vulgaris), and cotton (Gossypium spp.) (Bernstein, 1975); salinity issues in turfgrass situations are likely at a similar threshold of $5 \mathrm{dS} \cdot \mathrm{m}^{-1}$ (Christians et al., 2017). For soil remediation, because composts are blended with on-site soils, composts with EC values more than 4 to 5 $\mathrm{dS} \cdot \mathrm{m}^{-1}$ can still be used if the overall EC of the soil:compost mix is less than $5 \mathrm{dS} \cdot \mathrm{m}^{-1}$, or if there is ample irrigation water available to leach excessive salts or nutrients before they could negatively affect a germinating seedling (Gondek et al., 2020). In the case of a fast-germinating $(5-10 \mathrm{~d})$ turfgrass species, it may be important to leach a soil profile amended with a high-EC compost before sowing seed or germination. Multiple leaching events have been shown to reduce compost EC from initial values of 4.82 to 8.30 $\mathrm{dS} \cdot \mathrm{m}^{-1}$ to 0.35 to $0.90 \mathrm{dS} \cdot \mathrm{m}^{-1}$ (Fornes et al., 2010); however, this would raise concerns regarding nutrientheavy runoff or leachate (Flury et al., 2015; McPhillips et al., 2017). It is unknown if adequate leaching could be performed within a short timeframe (5-10 d) to allow for reduction of soil solution EC before turfgrass seed germination.

Recommendations of compost use in turfgrass situations are based on volumetric parameters. Linde and Hepner (2005) found that incorporating biosolid compost in a 33\% volume ratio resulted in improved color ratings and increased density of kentucky bluegrass [KBG (Poa pratensis)] compared with synthetic fertilizer treatments. Over a 3-year period, turfgrass growth and quality of a mixture of tall fescue (Schedonorus arundinaceus), KBG, and perennial ryegrass [PR (Lolium perenne)] were improved by the incorporation of a mixedsource compost at a volume of $20 \%$ to 33\% (Evanylo et al., 2016). Establishment of KBG was increased with the incorporation of as little as $10 \%$ volume of poultry litter compost (Mandal et al., 2013). Stahnke et al. (2000) recommended a maximum of $20 \%$ compost by volume for cool-season lawns. These research trials suggested that using a volumetric approach to compost incorporation could yield suboptimal results because of a suggested range of $10 \%$ to $33 \%$ compost, depending on the compost source and turfgrass species. Volume should not be the sole determinant of compost application rates; therefore, there is a need for additional metrics for further development of compost incorporation recommendations. Development of a more precise recommended compost incorporation range based on compost EC or $\mathrm{pH}$ is necessary to reduce material and labor costs by incorporating the minimal amount of compost that yields the optimal benefit. Some communities provide rebates to homeowners for adding compost to lawns to improve water infiltration (Iowa Department of Natural Resources, 2009); therefore, research is needed to further develop compost use guidelines.

Compost nitrate content is also a concern during turfgrass establishment because of potential nitrate leaching and subsequent water quality issues during the 20-week period after turfgrass seeding (Easton and Petrovic, 2004), but guidelines regarding compost nitrate parameters are limited or linked to EC measurements. Avoidance of high nutrient levels by adjusting seeding timing has been proposed. Excessive ammonium nitrogen levels in biosolid-amended soil resulted in a 2- to 3-week delay in KBG establishment (Linde and Hepner, 2005). O'Brien and Barker (1996) found that delaying seeding by $14 \mathrm{~d}$ in municipal waste compost-amended soil containing up to $2300 \mathrm{ppm}$ ammonium nitrogen increased PR germination by $23 \%$ compared with seeding at the day of compost application. Because fast groundcover is desired to limit soil erosion, turfgrass contractors could not allow for a $>14-d$ fallow period before seeding (Iowa Department of Natural Resources, 2006); therefore, appropriate limitations measured by EC or by nitrogen content should be established.

Compost physical, chemical, and biological properties vary greatly because of the type of materials and processes used to produce a compost, which consequently affect the leachate composition and content (Chatterjee et al., 2013). Therefore, linking recommended compost usage rates to physical or chemical properties of a compost would allow for greater precision when using compost from different sources and different production methods, thereby yielding improved establishment parameters in a turfgrass situation. The objective of this project was to measure the effects of differing compost incorporation rates on perennial ryegrass establishment through leachate $\mathrm{pH}, \mathrm{EC}$, and nitrate content. The hypothesis was that as the compost incorporation rate increases, turfgrass germination would increase until the compost incorporation rate becomes detrimental to turfgrass germination because of the increased root zone nitrate content and EC levels. We propose this hypothesis because high levels of ions in solution, such as nitrate or overall ions measured by EC, may inhibit water imbibition by seeds or dehydrate emerging radicles of tender seedlings.

\section{Materials and methods}

COVID IMPACT STATEMENT. Both parts of this trial were scheduled to occur under controlled environment conditions in a greenhouse, but the closing of the Iowa State University campus and halting of all on-campus research in Mar. 2020 warranted a shift in the project location to an enclosed low tunnel at the off-campus research farm.

This trial consisted of two parts: a topsoil experiment and a subsoil experiment. The topsoil experiment was conducted at the Iowa State University Horticulture Research Station near Ames (lat. $46^{\circ} 06^{\prime} \mathrm{N}$, long. $\left.93^{\circ} 35^{\prime} \mathrm{W}\right)$ using various ratios of a native field topsoil [Spillville loam: $\mathrm{pH}, 6.8 ; 78$ ppm nitrogen $(\mathrm{N}) ; 92$ ppm phosphorus $(\mathrm{P}) ; 410$ ppm potassium $(\mathrm{K}) ; 7.0 \%$ organic matter (Mehlich 3 analytical method)], sampled to a depth of $15 \mathrm{~cm}$ and a compost $[\mathrm{pH}$, 9.0; EC, $6.74 \mathrm{dS} \cdot \mathrm{m}^{-1} ; 9700 \mathrm{ppm} \mathrm{N}$; 6200 ppm P; 15,300 ppm K (Mehlich 3 analytical method)]. Compost originated from mixed sources of food waste, greenhouse waste, dairy manure, and equine manure. Compost was processed in windrows at 60 to $71^{\circ} \mathrm{C}$ for the first 2 months, at 49 to $60^{\circ} \mathrm{C}$ for the next 2 months, and then cooled/matured at less than $38^{\circ} \mathrm{C}$ for the final 2 months. 
Windrows were turned twice per week during these periods. Preliminary methodology experiments were conducted during July and Aug. 2020, followed by the topsoil experiment in Sept. and Oct. 2020. The topsoil experiment was conducted in a modified low tunnel equipped with roof vents and roll-up sides, effectively mimicking outdoor weather conditions while eliminating natural precipitation interference (mean \pm SD: $6.8 \pm$ $2.8^{\circ} \mathrm{C}$ daily low temperature; $17.6 \pm$ $3.9^{\circ} \mathrm{C}$ daily high temperature; $68.1 \%$ $\pm 6.8 \%$ daily relative humidity). The subsoil experiment was conducted in the Department of Horticulture greenhouses on the Iowa State University campus in Ames during Nov. and Dec. 2020 using various ratios of a clay subsoil [Canisteo clay loam: pH, 7.6; 2 ppm N; 3 ppm P; 90 ppm $\mathrm{K} ; 0.9 \%$ organic matter (Mehlich 3 analytical method)] and the same compost source as that used for the topsoil experiment. Greenhouse conditions were $22^{\circ} \mathrm{C}$ during the day and night, with a daylength extended to $16 \mathrm{~h}$ by supplemental light intensity of 300 to $350 \mu \mathrm{mol} \cdot \mathrm{m}^{-2} \cdot \mathrm{s}^{-1}$. Experimental units of both experiments were arranged in a randomized complete block design with five replications. Treatments were two PR cultivars, Accent (salt-sensitive) and Spyglass (salt-tolerant) (Jacklin Seed by Simplot, Delco, ID), that were each planted on soil:compost ratios of 100:0, 80:20, 70:30, 60:40, 50:50, 40:60, and 0:100 by volume. Corresponding volumes were determined from the bulk density of oven-dried soil (topsoil: $1.26 \mathrm{~g} \cdot \mathrm{cm}^{-3}$; subsoil: $\left.2.03 \mathrm{~g} \cdot \mathrm{cm}^{-3}\right)$ and compost $(0.77$ $\left.\mathrm{g} \cdot \mathrm{cm}^{-3}\right)$ separately dried in an oven at $104^{\circ} \mathrm{C}$ for $72 \mathrm{~h}$ (Grossman and Reinsch, 2002). Dried material was then mixed at corresponding ratios before being packed into 10 -inch-tall $\times 4$-inch-diameter polyvinylchloride rooting tubes to the corresponding bulk density in relation to the soil:compost ratios. Tubes were filled to a height of only 8.5 inches to leave room for leachate water procedures and to ensure no seed loss occurred during establishment. The PR cultivars were seeded at $8 \mathrm{lb} / 1000 \mathrm{ft}^{2}$ and received no supplemental fertility throughout the trial. Irrigation was applied for $2 \mathrm{~min}$ at a rate of four times per day during the first week after sowing (Trio-Spray emitters; Hunter Industries, San Marcos, CA). The water application rate was 0.25 $\mathrm{cm} \cdot \mathrm{min}^{-1}$. During the second week, irrigation was reduced to $2 \mathrm{~min}$ at a rate of two times per day; then, it was further reduced to $2 \mathrm{~min}$ at a rate of once per day for the remainder of the experiment. This irrigation scheduling was chosen to allow for optimal seed germination while preventing later plant wilt and avoiding excess irrigation to not overly leach the soil:compost treatments by irrigation alone (Christians et al., 2017). Application of fungicides, insecticides, or herbicides was not necessary.

The PGC was assessed beginning at $\mathrm{l}$ week after seeding and, subsequently, three times weekly. The State of Iowa requires uniform vegetative cover of at least $70 \%$ after any soil-disturbing activities; therefore, our minimally acceptable PGC was set at the slightly more conservative value of $75 \%$ to ensure compliance with state law (Iowa Department of Natural Resources, 2018). The PGC was determined by performing a digital image analysis (Karcher et al., 2017). Images were collected using a digital camera (G9X; Canon, Tokyo, Japan) attached to a light box described by Thoms et al. (2011) and analyzed using digital software (71-176 hue range; 25-65 saturation range; TurfAnalyzer ver. 1.0.4) as described by Karcher et al. (2017). Leachate was collected weekly beginning $7 \mathrm{~d}$ after seeding (DAS) using a modified pourthru method (Whipker et al., 2001). As part of the leaching process, the trial was irrigated for $45 \mathrm{~min}$ and then allowed to drain for $1 \mathrm{~h}$. A collection basin was then placed under each rooting tube, and $75 \mathrm{~mL}$ of distilled water was poured on the surface. Leachate was collected until 40 to $50 \mathrm{~mL}$ was obtained; then, it was immediately measured for $\mathrm{pH}$ and $\mathrm{EC}$ using a handheld meter (HI9813-6; Hanna Instruments, Smithfield, RI) and calibrated on each collection date using standards and adjustments for temperature conditions. Then, leachate samples were refrigerated at $3.3^{\circ} \mathrm{C}$ until they were analyzed for nitrate content.

The weekly leachate nitrate content was analyzed according to the procedures of Hood-Nowotny et al. (2010), with some modifications. Leachate samples were diluted with distilled water by $20 \times(4.75 \mathrm{~mL}$ distilled water and $0.25 \mathrm{~mL}$ leachate) to allow for reading using a microplate spectrophotometer (Epoch; Biotek Instruments, Winooski, VT). Leachate samples were pipetted into 96-well plates using a microplate sample processor (Precision XS, Biotek Instruments). Spectrophotometer readings at $540 \mathrm{~nm}$ were converted into nitrate parts per million (ppm) using a known standard calibration curve. The $150-\mathrm{ppm}$ nitrate threshold was chosen because Christians et al. (1979) found that $125 \mathrm{ppm} \mathrm{N}$ yielded maximum tissue production in KBG and because PR tolerates slightly greater salt levels than KBG (RoseFricker and Wipff, 2001).

Data were subjected to an analysis of variance (ANOVA) using a repeated measures analysis to determine significant soil:compost treatment and cultivar effects using the date as the repeated measure (SAS ver. 9.4; SAS Institute, Cary, NC). Means were calculated using the general linear model in SAS. Means were separated with Fisher's least significant difference test at the $0.05 P$ level and calculated using the standard error from the SAS PROC MIXED procedure when $\mathrm{F}$ tests indicated a significant effect or interaction. Each experiment was analyzed separately.

\section{Results}

An abbreviated ANOVA table is presented in Table 1 , which shows the sums of squares by rating the parameter and experiment. Only statistically significant results are presented.

EC. Soil:compost treatment $x$ date interaction was present on all leachate collection dates in both experiments (Table 1). For the topsoil experiment, at 7 DAS, compost mixes of $\geq 30 \%$ resulted in EC in excess of the $4.0-\mathrm{dS} \cdot \mathrm{m}^{-1}$ threshold (Fig. 1). By 14 DAS, the $30 \%$ mixture decreased to an acceptable level, followed by the $40 \%$ mixture at 21 DAS. At 28 DAS, only the $100 \%$ compost treatment remained above the acceptable EC threshold. By 35 DAS, the 100\% compost treatment EC was acceptable but still greater than that of all other treatments. For the subsoil experiment, at 7 DAS, compost mixes more than $40 \%$ resulted in EC in excess of the acceptable threshold (Fig. 2). By 14 DAS, only the $100 \%$ compost treatment resulted in unacceptable 
Table 1. Abbreviated analysis of variance table showing treatment sums of squares for the evaluation of compost and soil mix ratios for perennial ryegrass establishment on topsoil and subsoil experiments at Ames, IA, in 2020.

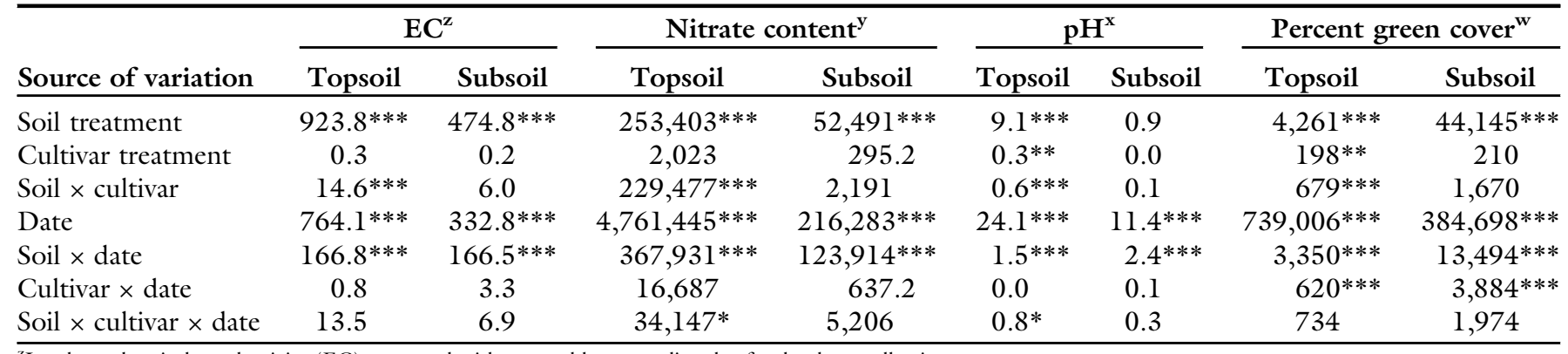

${ }^{\mathrm{z}}$ Leachate electrical conductivity (EC) measured with a portable meter directly after leachate collection.

${ }^{y}$ Nitrate content determined by dilution and analysis of leachate collected using a modified pour-thru leachate procedure.

${ }_{\mathrm{pH}}^{\mathrm{pH}}$ measured with a portable meter directly after leachate collection.

${ }^{w}$ Percent green cover determined by digital image capture using a light box, digital camera, and image analysis software.

$*, * *, * *$ Significant at $P<0.05,0.0005$, or 0.0001 , respectively.

EC levels. At 21 to 35 DAS, all treatments had acceptable EC levels, although the $60 \%$ and $100 \%$ compost treatments had greater EC levels than the $0 \%$ compost treatment.

Nitrate content. A soil:compost treatment $\times$ date interaction was present on three of five leachate collection dates in the topsoil experiment (Table 1). At 7 DAS, all treatments were more than the $150 \mathrm{ppm}$ nitrate threshold, with the $30 \%$ and $40 \%$ compost treatments having greater nitrate levels $(>400 \mathrm{ppm})$ than the $20 \%, 50 \%$, and $60 \%$ compost treatments $(451 \pm 200$ and $405 \pm 88 \mathrm{ppm}$, respectively; Fig. 1). At 14 and 21 DAS, the $60 \%$ compost treatment resulted in the greatest nitrate levels $(163 \pm 100$ and $168 \pm 103 \mathrm{ppm}$, respectively). Lower levels were measured in the $0 \%$ and $20 \%$ compost treatments at 21 DAS $(40 \pm 49$ and $23 \pm 27 \mathrm{ppm}$, respectively). In the subsoil experiment, a soil treatment $\times$ date interaction was present on two of five leachate collection dates (Table 1). At 7 DAS, all treatments were less than $150 \mathrm{ppm}$ nitrate, with the $100 \%$ compost treatment resulting in the greatest level $(139 \pm 69$ ppm $)$ compared with $3 \pm 1 \mathrm{ppm}$ in the $0 \%$ compost treatment, with other treatments having intermediate gradations (Fig. $2)$. At 14 DAS, the $0 \%$ compost treatment $(<1 \pm 0.3 \mathrm{ppm})$ resulted in less leachate nitrate than the $100 \%$ compost treatment $(39 \pm 65 \mathrm{ppm})$, with all other treatments being similar.

PH. The soil:compost treatment $x$ date interaction was present on all leachate collection dates in both experiments (Table 1). For the topsoil experiment, at 7 and 14 DAS, no treatments were more than the acceptable $\mathrm{pH}$ level of 8.0 (Troug, 1946), but differences were present (Fig. 1). At 21 to 35 DAS, the $100 \%$ compost treatment had a $\mathrm{pH}$ more than 8.0 , with the $60 \%$ compost treatment being similar on all dates but slightly below the $\mathrm{pH}$ of 8.0. For the subsoil experiment, at 14 DAS, although all treatments were similar, they were all also higher than the acceptable $\mathrm{pH}$ of 8.0 (Fig. 2). This trend continued at 21 DAS, except for the $0 \%$ compost treatment, which resulted in a lower, and acceptable, $\mathrm{pH}$ of 7.7. At 28 and 35 DAS, all treatments were within the acceptable $\mathrm{pH}$ range, but differences were only evident at 28 DAS: the $0 \%$ compost treatment resulted in a lower $\mathrm{pH}$ than the $50 \%$, $60 \%$, and $100 \%$ compost treatments.

Percent green cover. The soil:compost treatment $\times$ date interaction was present on five of 10 rating dates in the topsoil experiment (Table 1). The $0 \%$ compost treatment resulted in the lowest PGC for five rating dates [ $40 \%$ to $87 \%$ (Fig. 1)]. At 16 and 19 DAS, the $50 \%$ compost treatment resulted in greater PGC (48\% and $66 \%$, respectively) than the $0 \%$ and $100 \%$ compost treatments (40\% to $59 \%)$. At 21 DAS, the $30 \%$, $40 \%$, and $50 \%$ compost treatments were the first to reach $75 \%$ green cover, although the $20 \%$ and $60 \%$ compost treatments were similar (but $<75 \%$ green cover). At 23 and 28 DAS, all treatments resulted in similar PGC except for the $0 \%$ compost treatment, which had less PGC. The cultivar $\times$ date interaction was present only at 21 and 23 DAS, at which time the sensitive cultivar resulted in greater PGC than the tolerant cultivar by
$3.0 \%$ and $4.5 \%$ green cover, respectively (data not shown). For the subsoil experiment, the soil treatment $x$ date interaction was reported on 12 of 13 rating dates (Table 1 ). Before any treatments reached $75 \%$ green cover, at 9 to 23 DAS, the $0 \%$ and $100 \%$ compost treatments resulted in lower PGC (9\% to $46 \%$ and $9 \%$ to $61 \%$, respectively) than at least two other treatments (Fig. 2). At 26 DAS, four treatments reached more than $75 \%$ green cover, with the $40 \%$ and $60 \%$ compost treatments resulting in greater PGC $(>80 \%)$ than the $0 \%$, $20 \%$, and $100 \%$ compost treatments $(<72 \%$ green cover). At 28 to 35 DAS, treatments with $\geq 60 \%$ compost consistently resulted in more than $75 \%$ green cover, whereas the $0 \%$ and $20 \%$ compost treatments never reached $75 \%$ green cover. The cultivar $\times$ date interaction was present on six of 13 rating dates. At 12 to 19 DAS, the salt-sensitive cultivar resulted in $4.8 \%$ to $7.8 \%$ more green cover than the salt-tolerant cultivar. At 28 and 30 DAS, the salt-tolerant cultivar reached more than $75 \%$ green cover and resulted in $4.3 \%$ to $4.4 \%$ more green cover than the salt-sensitive cultivar (data not shown).

\section{Discussion}

Although some treatments resulted in unacceptable leachate EC levels in the topsoil experiment at 7 and 14 DAS, PGC differences on those dates were insignificant. The subsoil experiment resulted in the $0 \%$ and $100 \%$ compost treatments having lower PGC than other treatments through 21 DAS, even though only the $100 \%$ compost treatment resulted in an 

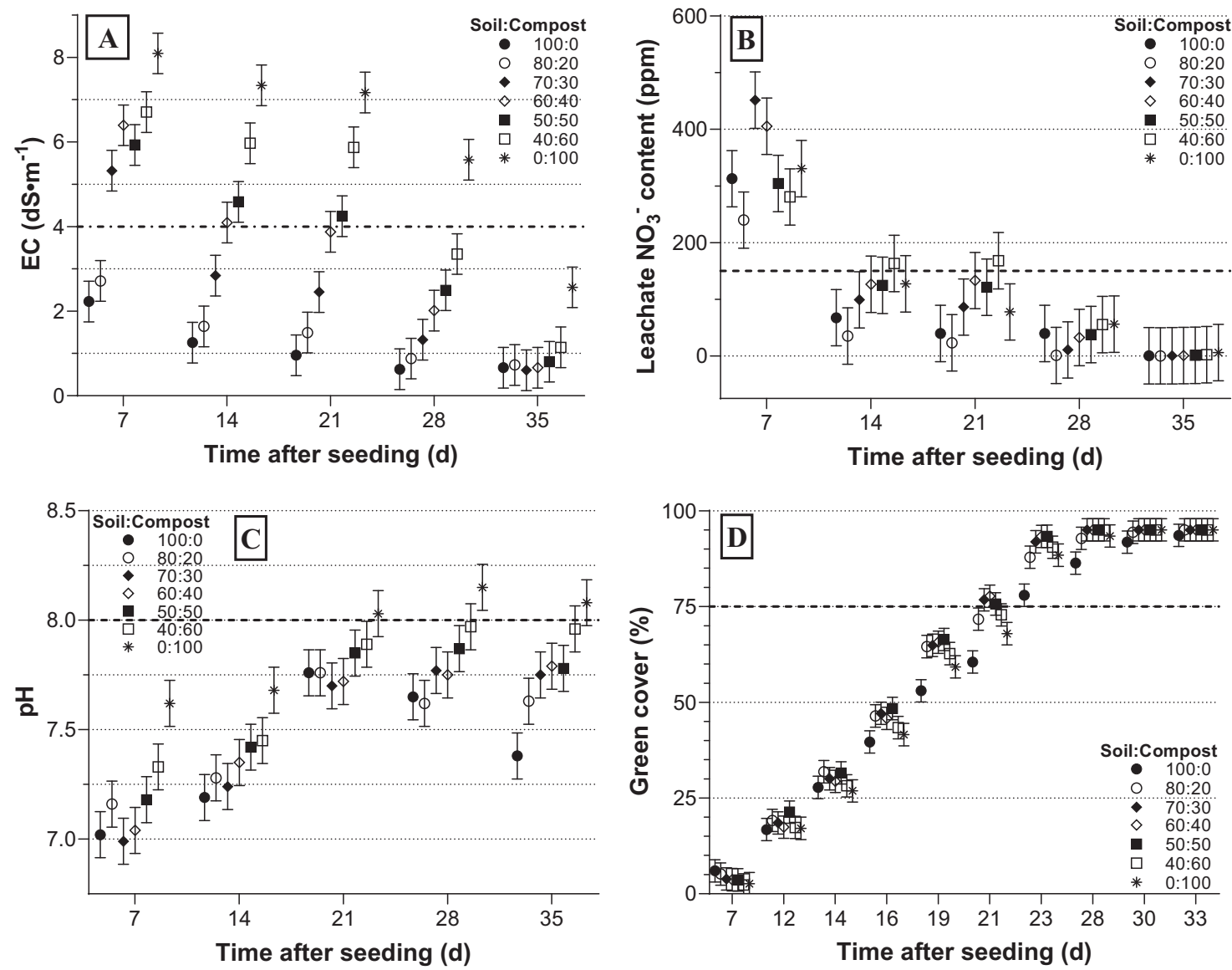

Fig. 1. Results by rating parameter averaged across two cultivars of perennial ryegrass on a loam topsoil amended with various percentages of a mixed-source mature compost at Ames, IA, in 2020. (A) Leachate electrical conductivity (EC). (B) Leachate nitrate $\left(\mathrm{NO}_{3}{ }^{-}\right)$content. (C) Leachate $\mathrm{pH}$. (D) Percent green cover data. Data collection occurred only on days numerically represented, and comparisons were made within and across these groups; the $x$-axis is not continuous. The dashed line at $4 \mathrm{dS} \cdot \mathrm{m}^{-1}$ in (A) represents the maximum recommended EC to likely avoid salt stress issues. The dashed line at $150 \mathrm{ppm}$ in (B) represents the maximum recommended leachate nitrate content to likely avoid perennial ryegrass salt stress issues. The dashed line at $\mathrm{pH} 8.0$ in $(\mathrm{C})$ represents the maximum recommended $\mathrm{pH}$ to likely avoid plant nutrient availability issues. The dashed line at $75 \%$ green cover in (D) represents the minimum recommended percent green cover for a treatment to be considered adequately established. T-bars represent the least significant difference between treatments within a date; 1 $\mathrm{dS} \cdot \mathrm{m}^{-1}=1 \mathrm{mmho} / \mathrm{cm}, 1 \mathrm{ppm}=1 \mathrm{mg} \cdot \mathrm{L}^{-1}$.

unacceptable EC level on a significant PGC date. Through 21 DAS in both experiments, the $0 \%$ and $100 \%$ compost treatments lagged behind treatments containing both components, likely because of the greater bulk density of the $0 \%$ compost treatments and the initially elevated EC levels of the $100 \%$ compost treatments. Contrary to our hypothesis, it did not seem that elevated EC levels resulted in reduced germination, but rather more likely caused delayed establishment, as seen in the 2d delay of the $100 \%$ compost treatment in reaching $75 \%$ green cover compared with when other treatments reached the same benchmark. This is much shorter than the delay observed when an immature compost was used (Linde and Hepner, 2005). At the end of each experiment, regardless of leachate EC, all treatments ended with similarly high PGC, except for the $100 \%$ and $80 \%$ subsoil treatments (bulk densities of 2.03 and $1.78 \mathrm{~g} \cdot \mathrm{cm}^{-3}$, respectively); their growth was likely stunted by rootimpeding soil bulk density values more than $1.6 \mathrm{~g} \cdot \mathrm{cm}^{-3}$ (O'Neil and Carrow, 1983 ) and, perhaps, by soil component P levels less than 10 ppm (Kreuser et al., 2012). Because of the immobility of $P$ in soil, it was determined that an application of $\mathrm{P}$ was not warranted for either soil because the plant may not uptake it during the experiment because of the short root length. More research is needed to determine if the lack of $\mathrm{P}$ limited PR establishment in this study.

When comparing the leachate nitrate content to PGC, we observed a trend of nitrate content differences occurring early in the trial when differences in PGC were not present. It has been reported that most sodium salts leach from the root zone in the first few leaching events (Ksheem et al., 2015), which likely happened in this trial. In the topsoil experiment, the treatment with the greatest leachate nitrate content $(60 \%$ compost $)$ was among the group of greatest PGC, leading us to reject our hypothesis in the case of this topsoil. In the subsoil experiment, the $100 \%$ compost treatment resulted in a greater leachate nitrate content than only that of the $0 \%$ compost treatment, whereas both resulted in the lowest PGC of all treatments. Overall, the leachate nitrate content was low for most dates; therefore, nitrate leaching 

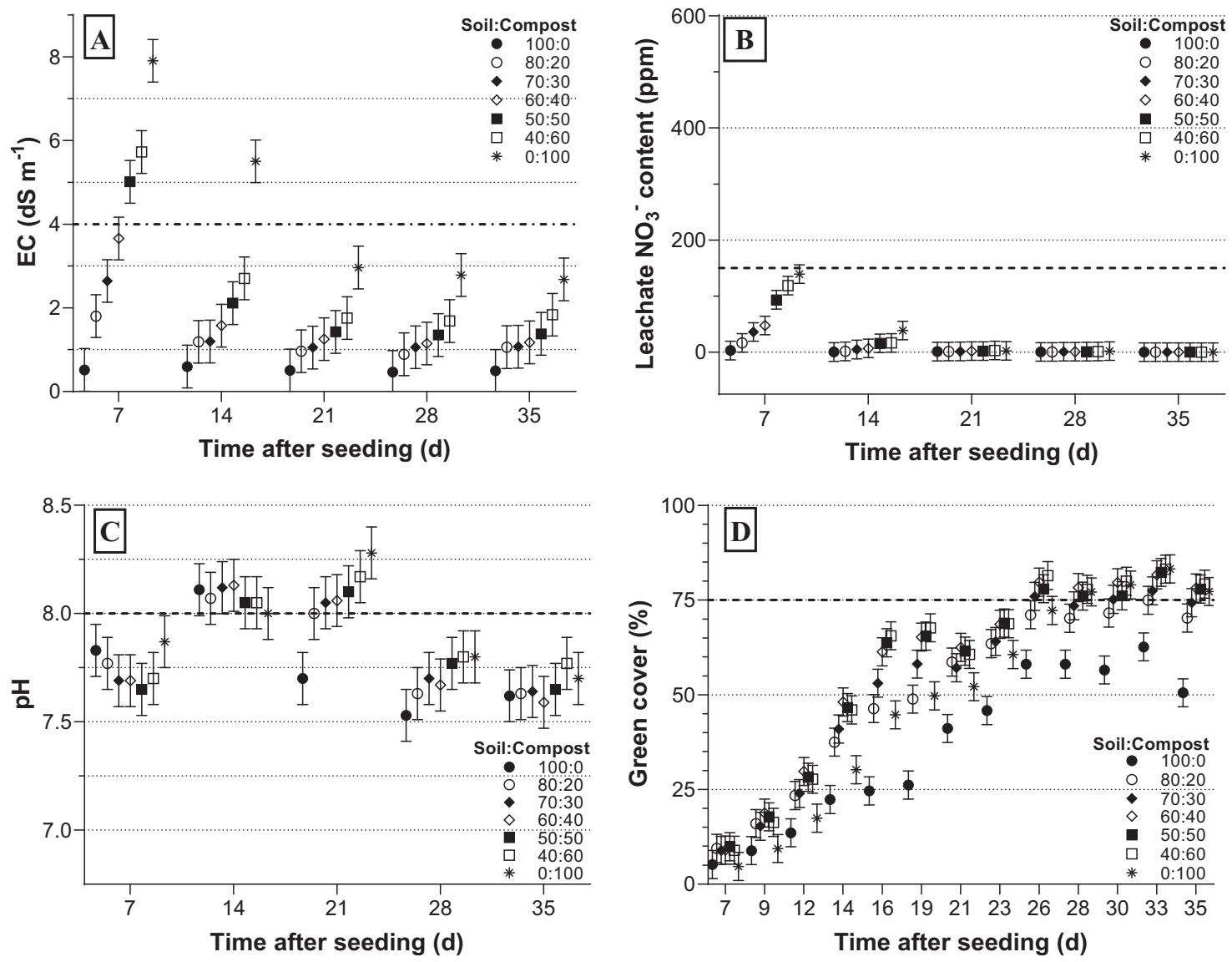

Fig. 2. Results by rating parameter averaged across two cultivars of perennial ryegrass on a clay subsoil amended with various percentages of a mixed-source mature compost at Ames, IA, in 2020. (A) Leachate electrical conductivity (EC). (B) Leachate nitrate $\left(\mathrm{NO}_{3}{ }^{-}\right)$content. (C) Leachate $\mathrm{pH}$. (D) Percent green cover data. Data collection occurred only on days numerically represented, and comparisons are made within and across these groups; the $\mathrm{x}$-axis is not continuous. The dashed line at 4 $\mathrm{dS} \cdot \mathrm{m}^{-1}$ in (A) represents the maximum recommended EC to likely avoid salt stress issues. The dashed line at $150 \mathrm{ppm}$ in (B) represents the maximum recommended leachate nitrate content to likely avoid perennial ryegrass salt stress issues. The dashed line at $\mathrm{pH} 8.0 \mathrm{in}(\mathrm{C})$ represents the maximum recommended $\mathrm{pH}$ to likely avoid plant nutrient availability issues. The dashed line at $75 \%$ green cover in (D) represents the minimum recommended percent green cover for a treatment to be considered adequately established. $\mathrm{T}$-bars represent least the significant difference between treatments within a date; 1 $\mathrm{dS} \cdot \mathrm{m}^{-1}=1 \mathrm{mmho} / \mathrm{cm}, 1 \mathrm{ppm}=1 \mathrm{mg} \cdot \mathrm{L}^{-1}$.

of a mature compost amended into a subsoil may not be an issue, regardless of how much compost is used. Leachate $\mathrm{pH}$ comparisons yielded similar results. For both experiments at 21 DAS, the treatment with the greatest leachate $\mathrm{pH}$ ( $100 \%$ compost) resulted in the second lowest PGC. However, by 28 DAS, the same treatment was less than $\mathrm{pH} 8.0$ and among the grouping of the greatest PGC. On all other dates, one of the two factors was insignificant. This suggests that if too much compost is used and the soil solution is more than $\mathrm{pH}$ 8.0, turfgrass establishment may be delayed until the $\mathrm{pH}$ is reduced through irrigation leaching, especially in a subsoil. This trial is in agreeance with the recommendation of Heyman et al. (2019) that planting into $100 \%$ compost should not be performed because of its unnecessity and potential nutrient leaching to groundwater. Irrigation water $\mathrm{pH}$ may have been a factor as well. The topsoil had a $\mathrm{pH}$ of 6.8 , whereas the irrigation water had a $\mathrm{pH}$ of 7.7; therefore, those factors and the fact that the compost starting $\mathrm{pH}$ was 9.0 likely accounted for the general increase in $\mathrm{pH}$ as the topsoil experiment progressed. The overall higher $\mathrm{pH}$ in the subsoil experiment could be attributable to a higher starting $\mathrm{pH}$ of the subsoil (7.6) and a slightly higher irrigation water $\mathrm{pH}$ (7.8). In both experiments, $\mathrm{pH}$ levels did not seem to have a negative effect because the final PGC was acceptable for most treatments in both experiments.

In the case of this mature mixedsource compost, our findings of increased PGC with $20 \%$ or more compost align with previous recommendations for compost application in a turfgrass system of incorporating compost on a $10 \%$ to $33 \%$ volume ratio (Evanylo et al., 2016; Landschoot, 1995; Linde and Hepner, 2005; Mandal et al., 2013; Stahnke et al., 2000). We only tested one compost source and age. Future research should incorporate additional compost sources and ages while continuing to evaluate initial compost characteristics in relation to turfgrass establishment success. The PR could be more susceptible to initially high leachate $\mathrm{N}$ content or EC values compared with a slower germinating species such as KBG, which would establish well after initial leachate events removed excess salts or nutrients. Our container trial results suggest that with a suitable topsoil, 
compost incorporation may be unnecessary to obtain acceptable PGC within a reasonable timeframe, and that a narrower recommendation range of 30\% to $40 \%$ compost incorporation into a subsoil could achieve faster establishment with low potential for nitrate leaching, along with the known longterm benefits of compost incorporation (Johnson et al., 2006). However, field trials should be performed to confirm this. Our trial results suggest that early/initial leaching events, through irrigation or data collection, allowed a quick-germinating species to tolerate initially high $\mathrm{EC} /$ nitrate levels enough to achieve acceptable establishment. Although we did observe increased PGC using compost treatments containing up to $60 \%$ in both independent experiments, similar results were obtained by using $20 \%$ to $30 \%$ compost; incorporating more than $20 \%$ to $30 \%$ compost would not be economically or logistically feasible in most situations. Our subsoil trial results also suggest that compost incorporation improves establishment and PGC without negative effects (increased EC or nitrate leaching) on nutrient-deficient subsoils. Our results suggest that the optimal range for compost amending of a subsoil is $30 \%$ to $40 \%$ when using this compost under our experimental conditions.

The original intent of this study was to develop incorporation rate guidance based on the compost physiochemical parameters of $\mathrm{N}$ and $\mathrm{EC}$. Although we did not find that the initial source compost $\mathrm{N}$ or EC content were valuable predictors that could guide incorporation rates, our research adds to a growing consensus of experimental findings indicating that a 30\% compost-to-soil incorporation rate is beneficial for plant growth and establishment despite different native soils and compost sources. Furthermore, our finding of slightly more compost $(30 \%$ to $40 \%)$ in degraded subsoils seems to fit logically with soil chemical and physical properties that would be redressed by compost additions.

\section{Literature cited}

Bernstein, L. 1975. Effects of salinity and sodicity on plant growth. Annu. Rev. Phytopathol. 13:295-312, https://doi.org/ 10.1146/annurev.py.13.090175.001455.
Chatterjee, N., M. Flury, C. Hinman, and C.G. Cogger. 2013. Chemical and physical characteristics of compost leachates A review. Washington State Dept. Trans. Res. Rpt. WA-RD 819.1. 6 Oct. 2021. <https://www.wsdot.wa.gov/research/ reports/fullreports/819.1.pdf $>$.

Christians, N.E., A.J. Patton, and Q.D. Law. 2017. Fundamentals of turfgrass management. 5th ed. Wiley, Hoboken, NJ, https:// doi.org/10.1002/9781119308867.

Christians, N.E., D.P. Martin, and J.F. Wilkinson. 1979. Nitrogen, phosphorus, and potassium effects on quality and growth of kentucky bluegrass and creeping bentgrass. Agron. J. 71:564-567, https://doi.org/10.2134/agronj1979.00 $021962007100040011 \mathrm{x}$.

Cogger, C.G. 2005. Potential compost benefits for restoration of soils disturbed by urban development. Compost Sci. Util. 13:243-251, https://doi.org/1080/106 5657X.2005.10702248.

Easton, Z.M. and A.M. Petrovic. 2004. Fertilizer source effect on ground and surface water quality in drainage from turfgrass. J. Environ. Qual. 33:645-655, https://doi.org/10.2134/jeg2004.0645.

Evanylo, G.K., S.N. Porta, J. Li, D. Shan, J.M. Goatley, and R. Maguire. 2016. Compost practices for improving soil properties and turfgrass establishment and quality on a disturbed urban soil. Compost Sci. Util. 24:136-145, https://doi. org/10.1080/1065657X.2015.1096866.

Flury, M., J.M. Mullane, M.K. Chahal, and C. Cogger. 2015. Experimental evaluation of compost leachates. Washington State Dept. Trans. Res. Rpt. WA-RD 848.1. 6 Oct. 2021. <https://www.wsdot.wa.gov/ research/reports/fullreports/848.1.pdf $>$.

Fornes, F.C., C. Carrion, R. Garcia-dela-Fuente, R. Puchades, and M. Abad. 2010. Leaching composted lignocellulosic wastes to prepare container media: Feasibility and environmental concerns. J. Environ. Manage. 91:1747-1755, https://doi.org/ 10.1016/j.jenvman.2010.03.017.

Gondek, M., D.C. Weindorf, C. Thiel, and G. Kleinheinz. 2020. Soluble salts in compost and their effects on soil and plants: A review. Compost Sci. Util. 28:59-75, https://doi.org/10.1080/1065657X. 2020.1772906 .

Grossman, R.B. and T.G. Reinsch. 2002. Bulk density and linear extensibility: Core method, p. 208-228. In: J.H. Dane and G.C. Topp (eds.). Methods of soil analysis. Part 4, Physical methods. Soil Sci. Soc. Amer., Madison, WI.

Heyman, H., N. Bassuk, J. Bonhotal, and T. Walter. 2019. Compost quality recommendations for remediating urban soils.
Int. J. Environ. Res. Public Health 16: 3191, https://doi.org/10.3390/ijerphl6 173191.

Hood-Nowotny, R., N.H.-N. Umana, E. Inselbacher, P. Oswald-Lachouani, and W. Wanek. 2010. Alternative methods for measuring inorganic, organic, and total dissolved nitrogen in soil. Soil Sci. Soc. Amer. J. 74:1018-1027, https://doi. org/10.2136/sssaj2009.0389.

Iowa Department of Natural Resources. 2006. Iowa construction site erosion control manual. Chapter 2: Vegetation and soil stabilization control measures. 16 Feb. 2021. $<$ http://publications.iowa.gov/8127/1/ const_erosion.pdf $>$.

Iowa Department of Natural Resources. 2009. Iowa storm water management manual. Chapter 5: Infiltration practices. 5 Feb. 2021. <https://www.iowadnr.gov/ Environmental-Protection/Water-Quality/ NPDES-Storm-Water/Storm-WaterManual $>$.

Iowa Department of Natural Resources. 2018. National pollutant discharge elimination system (General permit No. 2). 15 Nov. 2021. <https://www.iowadnr.gov/ Portals/idnr/uploads/water/npdes/gp2 . pdf $>$.

Johnson, G.A., Y.L. Qian, and J.G. Davis. 2006. Effects of compost topdressing on turf quality and growth of kentucky bluegrass. Appl. Turfgrass Sci. 3:1-7, https:// doi.org/10.1094/ats-2006-0113-01-rs.

Karcher, D.E., C.J. Purcell, M.D. Richardson, L.C. Purcell, and K.W. Hignight. 2017. A new Java program to rapidly quantify several turfgrass parameters from digital images. 2017 Amer. Soc. Agron., Crop Sci. Soc. Amer., Soil Sci. Soc. Amer., Abstr. 108681.

Kreuser, W.C., P. Pagliari, and D.J. Soldat. 2012. Creeping bentgrass putting green Mehlich-3 soil test phosphorus requirements. Crop Sci. 52:1385-1392, https:// doi.org/10.2135/cropsci2011.08.0416.

Ksheem, A.M., J.M. Bennett, D.L. Antille, and S.R. Raine. 2015. Towards a method for optimized extraction of soluble nutrients from fresh and composted chicken manures. J. Waste Manage. 45:76-90, https://doi.org/10.1016/j.wasman.2015. 02.011

Landschoot, P.A. 1995. Using compost to improve turf performance. 30 Sept. 2021. <http://www.agronomy.psu.edu/ estension/turf/composts.html>.

Layman, R.M., S.D. Day, D.K. Mitchell, Y. Chen, J.R. Harris, and W.L. Daniels. 2016. Below ground matters: Urban soil rehabilitation increases tree canopy and speeds establishment. Urban For. Urban Green. 16: 
25-35, https://doi.org/10.1016/j.ufug. 2016.01.004.

Linde, D.T. and L.D. Hepner. 2005. Turfgrass seed and sod establishment on soil amended with biosolid compost. HortTechnology 15:577-583, https://doi.org/ 10.21273/HORTTECH.15.3.0577.

Mandal, M., R. Chandran, and J. Balasko. 2013. Amending subsoil with composted poultry litter-II: Effects on kentucky bluegrass (Poa pratensis) establishment, root growth, and weed populations. Agronomy 3:670-684, https://doi.org/10.3390/agro nomy3040670.

McPhillips, L., C. Goodale, and M.T. Walter. 2017. Nutrient leaching and greenhouse gas emissions in grassed detention and bioretention stormwater basins. J. Sustain. Water Built Environ., https://doi. org/10.1061/jswbay.0000837.

McGrath, D. and J. Henry. 2016. Organic amendments decrease bulk density and improve tree establishment and growth in roadside plantings. Urban For. Urban Green. 20:120-127, https://doi.org/10. 1016/j.ufug.2016.08.015.

O'Brien, T.A. and A.V. Barker. 1996. Evaluation of ammonium and soluble salts on grass sod production in compost. II. Delaying seeding after compost application. Commun. Soil Sci. Plant Anal. 27:77-85, https://doi.org/1080/00103629609369 545 .

O’Neil, K.J. and R.N. Carrow. 1983. Perennial ryegrass growth, water use, and soil aeration status under soil compaction. Agron. J. 75:177-180, https://doi.org/10.2134/ agronj1983.00021962007500020005x.

Rose-Fricker, C. and J.K. Wipff. 2001. Breeding for salt tolerance in cool-season turfgrasses. Int. Turfgrass Soc. Res. J. 9:206-212.

Sax, M.S., N. Bassuk, H. van Es, and D. Rakow. 2017. Long-term remediation of compacted urban soils by physical fracturing and incorporation of compost. Urban
For. Urban Green. 24:149-156, https:// doi.org/10.1016/j.ufug.2017.03.023.

Stahnke, G.K., S.E. Braun, R.S. Byther, A.L. Antonelli, and G. Chastagner. 2000. Home lawns (revised). Washington State Univ. Ext. Bul. 0482.

Thoms, A.W., J.C. Sorochan, J.T. Brosnan, and T.J. Samples. 2011. Perennial ryegrass and grooming affect bermudagrass traffic tolerance. Crop Sci. 51: 2204-2211, https://doi.org/10.2135/ cropsci2010.08.0489.

Troug, E. 1946. Soil reaction influence on availability of plant nutrients. Soil Sci. Am Proc. 11:305-308.

Turgeon, A.J. and J.E. Kaminski. 2019. Turfgrass management. Turfpath, State College, PA.

Whipker, B.E., T.J. Cavins, and W.C. Fonteno. 2001. 1, 2, 3's of PourThru. 6 Oct. 2021. < https://ag.montana.edu/pgc/ documents/PourThruHandoutl23s.pdf $>$. 